\title{
PENGARUH PEMBERIAN MINYAK DEEP FRYING TERHADAP PERUBAHAN HISTOPATOLOGI JANTUNG TIKUS PUTIH (Rattus novergicus strain wistar)
}

\author{
Lianda Destrin Nurfadilah ${ }^{1}$, Sri Adilla Nurainiwati ${ }^{2}$, S.M. Agustini ${ }^{3}$
}

Fakultas Kedokteran Universitas Muhammadiyah Malang, Jalan Bendungan Sutami No. 188A, Kota Malang, Kode Pos 65144, Indonesia

\begin{abstract}
ABSTRAK
Pengaruh Pemberian Minyak Deep Frying Terhadap Perubahan Histopatologi Jantung Tikus Putih (Rattus novergicus strain wistar). Latar belakang: Peningkatan harga minyak tiap tahunnya mengakibatkan banyak masyarakat menggunakan minyak goreng berulang kali sehingga mengakibatkan terbentuknya senyawa radikal bebas yang dapat menyebabkan nekrosis sel otot jantung. Tujuan: Penelitian ini bertujuan untuk membuktikan pengaruh pemberian minyak deep frying terhadap perubahan histopatologi jantung tikus putih (Rattus novergicus strain wistar). Metode: Penelitian ini merupakan true experimental menggunakan 20 ekor tikus, yang dibagi menjadi 4 kelompok dan diberi perlakuan selama 28 hari. Kelompok pertama diberikan pakan dan minum, kelompok II, III, IV diberikan 4x, 8x, 16x penggorengan. Tikus diberikan minyak deep frying dengan dosis $0.25 \mathrm{ml} / 100 \mathrm{~g} \mathrm{BB} /$ hari menggunakan sonde lambung. Setelah 28 hari dilakukan pengambilan jantung tikus dan dibuat sediaan dengan pengecatan Hematoksilin Eosin kemudian dilakukan pengamatan sel nekrosis jantung. Hasil penelitian: Uji one way ANOVA didapatkan nilai sig $=0,000(\mathrm{p}<0.01)$, terdapat pengaruh yang bermakna dari penggorengan berulang minyak deep frying terhadap nekrosis sel otot jantung. Uji Korelasi sig (2-tailed) = $0,000(\mathrm{p}<0.01)$ dengan uji regresi didapatkan nilai $\mathrm{R} 2=0,861$, nekrosis sel otot jantung dipengaruhi minyak deep frying sebesar 86.1\%. Kesimpulan: Pemberian minyak deep frying berpengaruh bermakna terhadap peningkatan jumlah sel nekrosis pada jantung tikus putih (Rattus novergicus strain wistar).
\end{abstract}

Kata Kunci: minyak deep frying, stres oksidatif, nekrosis sel otot jantung.

\section{ABSTRACT}

The Effect of Deep Frying Oil on Heart Histopathology Changes of White Rats (Rattus novergicus strain wistar). Background: Increased frying oil every years causes many sosiaties used repeated frying oil and result formation of free radicals that causes necrosis heart muscle cell. Objective: This research was carried out to investigate the effect of deep frying oil on heart muscle cell histopathology of white rat (Rattus novergicus strain wistar). Methods: This research is a true experimental that used 25 rats, they were divided into 4 groups. The first group was given feed and drink orally. The second, third, and fourth group were given $4 x, 8 x$ and $16 x$ deep frying oil. The rats were given deep frying oil at a dose of $0.5 \mathrm{ml} / 100 \mathrm{~g} \mathrm{BB} /$ day used gavage needle. After 28 day, taken part of heart. Then, made Haematoxilyn Eosin preparations and observation necrosis of heart muscle cell. Result: One way ANOVA test value sig $=0,000(p<0.01)$, there were significant influence of deep frying oil on increased necrosis heart muscle cell and regression test result was $\mathrm{R}=0,861$ which meant that necrosis of heart muscle cell can be affected by deep frying oil in 86.1\%. Conclusion: Deep frying oil given significant result on increased necrosis of heart muscle cell of white rat (Rattus novergicus strain wistar).

Key word: deep frying oil, oxidative stress, heart muscle cell necrosis

\section{PENDAHULUAN}

Deep frying adalah sistem menggoreng biasa bahan pangan, yaitu dengan cara bahan pangan yang digoreng terendam dalam minyak dan suhu minyak dapat mencapai $200-205^{\circ} \mathrm{C}$ atau $392-401^{\circ} \mathrm{F}$ (Ketaren, 2008). Cara memasak deep frying sering dijumpai di restoran dan juga di rumah, contoh makanan yang dapat dimasak dengan sistem deep frying adalah ayam, kacang, donat, kentang, dan bawang (Ghidurus, 2010). Pada tahun 2012, konsumsi minyak goreng di Indonesia yaitu 4.5-4.8 juta ton dan tahun 2013 diperkirakan mencapai 5.22 juta ton (Noeltgr, 2013). Menurut Kemendagri (2013) pada bulan Desember 2012 harga rata- rata minyak goreng curah adalah Rp 10.070/liter dan pada bulan Desember 2013 harga rata-rata minyak goreng curah adalah Rp 10.802/liter.

Kebutuhan akan minyak goreng semakin meningkat sedangkan harga minyak semakin naik dari tahun sebelumnya sehingga banyak orang menggunakan minyak goreng berulang kali dengan alasan menghemat (Rukmini, 2007). Konsumsi lemak yang berlebihan dengan pemanasan berulang dapat meningkatkan resiko aterosklerosis yang merupakan salah satu penyebab utama dari penyakit jantung koroner (Xian, 2012), menurut WHO 17,1 juta orang di dunia meninggal di tahun 2004 akibat penyakit kardiovaskular dan sekitar 7,2 juta 
orang diantaranya meninggal akibat penyakit jantung koroner. Penelitian Muazzes (2007) melaporkan bahwa proses menggoreng deep frying dapat menyebabkan terjadinya berbagai reaksi kimia, yaitu hidrolisis, oksidasi termal, dan polimerisasi termal. Hal ini dapat mempengaruhi kualitas makanan dan kesehatan manusia. Menurut penelitian Sartika (2009) penggunaan minyak deep frying yang dipakai lebih dari $4 \mathrm{x}$ penggorengan dapat menghasilkan senyawa radikal yang bersifat toksik bagi organ tubuh. Radikal bebas yang belebihan pada tubuh dapat menyebabkan kerusakan sel termasuk sel otot jantung. Perubahan minyak dengan metode penggorengan deep frying akan menghasilkan peroksida sebagai radikal bebas yang menyebabkan toksisitas dan kerusakan jaringan (Muazzez, 2007). Radikal bebas akan menginduksi terjadinya jejas sel otot jantung melalui peroksidasi lipid, yaitu teroksidasinya senyawa lipid yang memiliki dua atau lebih ikatan rangkap (polyunsaturated fatty acid/PUFA) (Anindiya, 2013). Rusaknya PUFA akan menyebabkan penurunan fungsi membran sel pada jantung terutama sebagai tempat difusi molekul antar sel ataupun intrasel sehingga dapat terjadi jejas sel yang reversible dan irreversible (Shastry, 2011).

Tujuan Penelitian secara umum adalah membuktikan pengaruh pemberian minyak deep frying terhadap perubahan histopatologi jantung tikus putih strain wistar. Sedangkan tujuan khususnya yaitu melihat pengaruh pemberian minyak deep frying $4 \mathrm{x}$ penggorengan terhadap nekrosis sel otot jantung tikus putih strain wistar, melihat pengaruh pemberian minyak deep frying $8 \mathrm{x}$ penggorengan terhadap nekrosis sel otot jantung tikus putih strain wistar, dan melihat pengaruh pemberian minyak deep frying 16x penggorengan terhadap nekrosis sel otot jantung tikus putih strain wistar. Adapun manfaat penelitian secara klinis adalah sebagai bukti ilmiah yang menyatakan tentang pengaruh pemberian minyak deep frying terhadap perubahan histologi jantung. Sedangkan manfaat secara akademik yaitu sebagai referensi penelitian selanjutnya dan memberikan pengetahuan mengenai perubahan histologi jantung yang disebabkan oleh minyak deep frying. Manfaat penelitian bagi masyarakat adalah memberikan pengetahuan kepada masyarakat tentang bahaya penggunaan berulang minyak deep frying terhadap perubahan sel jantung. Berdasarkan berbagai hasil penelitian tersebut, peneliti ingin meneliti lebih dalam mengenai adakah pengaruh pemberian minyak deep frying terhadap perubahan histopatologi jantung tikus putih strain wistar.

\section{METODE}

Penelitian ini merupakan penelitian eksperimental dengan menggunakan metode Post Test Only Control Group Design. Dilaksanakan selama 28 hari dan bertempat di Laboratorium Biomedik Fakultas Kedokteran Universitas Muhammadiyah Malang. Populasi penelitian adalah tikus putih strain wistar dewasa, jenis kelamin jantan, umur 2-3 bulan, berat badan 150-200 gram dengan kondisi sehat yang ditandai dengan pergerakannya aktif dan mata yang jernih. Sampel diambil secara random dari populasi tikus putih (Rattus norvegicus) strain wistar jantan dewasa sebagai hewan coba. Sampel terdiri atas 4 kelompok yang diambil secara random. Pada penelitian ini terdapat 4 kelompok yang diambil secara random dengan 4 perlakuan yang berbedabeda yaitu satu kelompok kontrol dan tiga kelompok perlakuan. Dosis dan lama penggorengan tersebut berdasarkan penelitian sebelumnya tentang efek minyak goreng pada beberapa organ tubuh dan penelitian pendahuluan yang dilakukan di Laboratorium Biomedik Fakultas Kedokteran Universitas Muhammadiyah Malang. Sampel diambil secara simple random sampling dari populasi tikus putih jantan (Rattus norvegicus strain wistar). Pengambilan sampel secara acak sederhana adalah bahwa setiap anggota atau unit dari populasi mempunyai kesempatan yang sama untuk diseleksi sebagai sampel (Satroasmoro, 2011).

Alat yang digunakan adalah kandang tikus, penutup kandang dari anyaman kawat, botol air, timbangan, tempat makan tikus, gunting dan pinset, tempat organ (botol sediaan), handscoon, pengait jaringn, sonde, mikroskop, botol film, neraca berat badan, spuit injeksi $3 \mathrm{ml}$, object glass, label. Sedangkan bahan untuk percobaan adalah hewan percobaan, makanan tikus, pengukuran variable, minyak deep frying, formalin 10\%, paraffin, alcohol 30\%, 50\%, 70\%, 85\%, 95\%, $100 \%$, xilol, hematoxilin dan Eosin, serta formalin.

\section{HASIL DAN PEMBAHASAN}

Hasil pengamatan preparat sel otot jantung secara histologi dilakukan menggunakan mikroskop cahaya dengan pembesaran 400x adalah sebagai berikut:
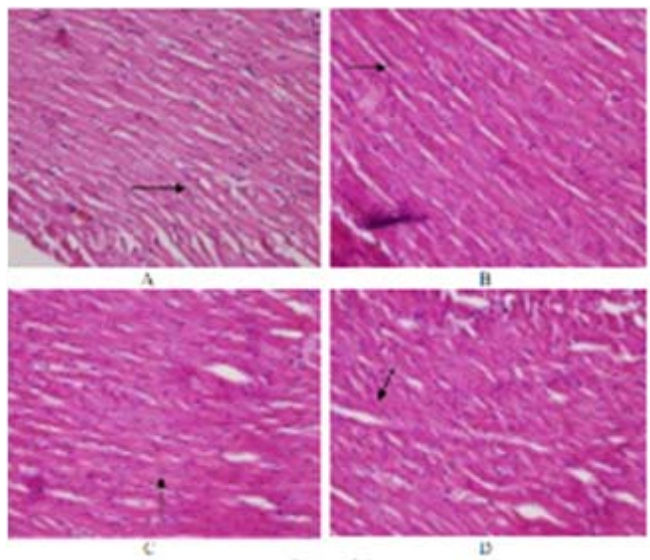

Gambar 1. Mikroskopis sel otot jantung dengan pembesaran 400x. A=kelompok kontrol (tanpa pemberian minyak deep frying) $\mathrm{B}=$ kelompok perlakuan I

(minyak deep frying $4 \mathrm{x}$ pengulangan) $\mathrm{C}=$ kelompok perlakuan II (minyak deep frying $8 \mathrm{x}$ pengulangan)

$\mathrm{D}=$ kelompok perlakuan III (minyak deep frying 16x pengulangan). Tanda panah ( $\longrightarrow$ ) sel otot jantung yang nekrosis

Setiap kelompok perlakuan terdapat 5 preparat sesuai dengan jumlah sampel yang sudah ditentukan kemudian setiap preparat dilakukan penghitungan sel per 10 lapang pandang dengan pembesaran 400x pengamatan sel diamati oleh spesialis patologi anatomi FK UMM (dr. Soebarkah Basuki, Sp.PA). Dalam pengujian pengaruh pemberian minyak deep frying terhadap perubahan histopatologi jantung tikus putih strain wistar, digunakan minyak $4 \mathrm{x}$ pengulangan, $8 x$ pengulangan, 16x pengulangan yang dilakukan selama 28 hari. Digunakan pembanding sebagai kontrol yaitu tidak diberikan minyak deep frying. Kemudian tikus dimatikan dan dilakukan proses pembedahan dengan tujuan pengambilan 
organ jantung untuk mengamati jumlah sel nekrosis pada sel otot jantung tikus putih strain wistar. Selanjutnya dilakukan pengamatan dalam 10 lapang pandang. Hasil penelitian sebagaimana tertera pada Tabel 1. sebagai berikut.

Tabel 1. Hasil penelitian jumlah nekrosis sel otot jantung tikus putih

\begin{tabular}{llllllll}
\hline Tikus & 1 & 2 & 3 & 4 & 5 & Rata-rata & SD \\
\hline K (-) & 8,5 & 3,9 & 3,9 & 3,2 & 4,7 & 4,840 & 2,1138 \\
P1 & 10,7 & 10,8 & 12,7 & 12,9 & 13,9 & 12,200 & 1,4000 \\
P2 & 14 & 17,8 & 23,4 & 20,9 & 19,3 & 19,080 & 3,5167 \\
P3 & 20,6 & 24 & 25,3 & 26,4 & 26,5 & 24,560 & 2,4337 \\
\hline
\end{tabular}

(Sumber : data primer 2014)

Berdasarkan Tabel 1. di atas terlihat bahwa penggorengan berulang minyak deep frying memberikan pengaruh terhadap jumlah sel nekrosis pada sel jantung tikus putih strain wistar. Adanya pengaruh pemberian minyak deep frying tersebut mulai terlihat, dimana jumlah sel nekrosis otot jantung tikus putih strain wistar menjadi lebih banyak setelah diberikan perlakuan (P1) yaitu minyak deep frying 4x penggorengan dengan dosis $0,5 \mathrm{ml} / 200 \mathrm{kgBB} / \mathrm{hari}$, dibandingkan dengan jumlah sel nekrosis pada kelompok kontrol. Kemudian jumlah sel nekrosis pada otot jantung tikus putih strain wistar cenderung semakin meningkat ketika diberi minyak deep frying $8 \mathrm{x}$ dengan dosis $0,5 \mathrm{ml} /$ $200 \mathrm{kgBB} /$ hari penggorengan dan 16x penggorengan dengan dosis $0,5 \mathrm{ml} / 200 \mathrm{kgBB} /$ hari. Adanya perbedaan jumlah sel nekrosis pada sel otot jantung tikus putih strain wistar dapat digambarkan dalam bentuk grafik sebagai berikut.

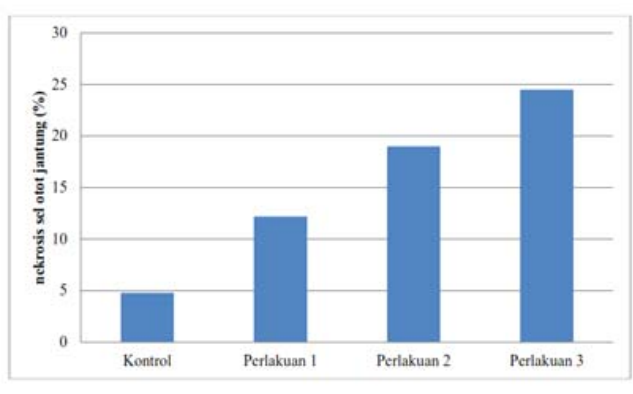

Gambar 2. Grafik jumlah nekrosis sel otot jantung tikus putih strain wistar

Dengan demikian, berdasarkan penilaian menurut ratarata jumlah sel nekrosis pada sel otot jantung tikus putih strain wistar tersebut, maka dapat disimpulkan bahwa pemberian minyak goreng deep frying $4 \mathrm{x}$ penggorengan dengan dosis $0,5 \mathrm{ml} / 200 \mathrm{kgBB} /$ hari, $8 \mathrm{x}$ penggorengan dengan dosis $0,5 \mathrm{ml} / 200 \mathrm{kgBB} /$ hari dan $16 \mathrm{x}$ penggorengan dengan dosis $0,5 \mathrm{ml} / 200 \mathrm{kgBB} /$ hari yang dilakukan selama 28 hari menunjukkan adanya perubahan pengaruh yang berbeda jika dibandingkan dengan kelompok kontrol terhadap jumlah sel nekrosis pada sel otot jantung tikus putih strain wistar.

Hasil uji normalitas menunjukkan bahwa kerusakan sel otot jantung didapatkan nilai sig $=0,426$ lebih besar dari $\mathrm{p}$ (0.05) yang berarti distribusi data bersifat normal. Denan demikian dapat dilakukan pengujian dengan ANOVA, karena kenormalan distribusi data terpenuhi. Uji homogenitas yang digunakan adalah uji Levene. Hasil uji Levene (Lampiran) menunjukkanbahwa kerusakan sel otot jantung didapatkan nilai sig $=0,479$ lebih besar dari $\mathrm{p}(0.05)$ yang berarti ragam (varians) data jumlah sel nekrosis otot jantung tikus putih strain wistar relatif homogen. Sehingga dapat dilakukan uji ANOVA karena homogenitas ragam data telah terpenuhi.

Tabel uji one way ANOVA menunjukkan bahwa setiap kelompok memiliki nilai sig $=0,000$ lebih kecil dari $\mathrm{p}(0,01)$ yang berarti terdapat pengaruh yang bermakna dari penggorengan berulang minyak deep frying terhadap nekrosis sel otot jantung tikus putih strain wistar. Uji selanjutnya adalah mengolah data menggunakan uji post hoc test sebagai uji pembanding berganda yaitu uji Tukey. Pada table uji Tukey menunjukkan bahwa kelompok kontrol memiliki perbedaan yang bermakna dengan semua kelompok perlakuan. Hal ini dibuktikan dengan nilai signifikan masingmasing kelompok lebih kecil dari p $(0,05)$.

Uji korelasi antara dosis penggorengan berulang minyak deep frying dan kerusakan sel otot jantung menunjukkan nilai sig (2-tailed) $=0,000<\mathrm{p}(0,01)$ dengan nilai pearson correlation $=0,928$. Hal ini menunjukkan korelasi yang sangat bermakna yang menunjukkan arah hubungan yang positif atau korelasi positif, yaitu semakin besar dosis penggorengan berulang minyak deep frying menyebabkan semakin banyak kerusakan sel otot jantung tikus putih strain wistar. Demikian sebaliknya, semakin kecil dosis penggorengan berulang minyak deep fryingmenyebabkan semakin sedikit kerusakan sel otot jantung tikus putih strain wistar. Uji regresi yaitu untuk mengetahui seberapa besar pengaruh pemberian penggorengan berulang minyak deep frying dengan nekrosis sel otot jantung tikus putih strain wistar, karena dari uji korelasi belum bisa menjelaskan hal tersebut. Nilai sig anova regresi $=0,000 \mathrm{p}<(0,05)$ yang berarti model regresi cocok secara bermakna. Nilai R2 yang terbentuk pada persamaan tersebut yaitu 0,861, artinya pengaruh pengulangan penggorengan minyak deep frying terhadap peningkatan kerusakan sel otot jantung sebesar $86,1 \%$. Sedangkan $13.9 \%$ kerusakan sel otot jantung tikus putih strain wistar dipengaruhi oleh faktor lain yang tidak diteliti dalam penelitian ini. Penelitian ini merupakan penelitian eksperimental dengan metode the post test only group design yang membuktikan pengaruh pemberian minyak deep frying terhadap perubahan histopatologi jantung tikus putih strain wistar yang dilakukan selama 28 hari.

Pada penelitian ini dilakukan uji kuantitatif dengan mengamati sel otot jantung secara mikroskopik. Hasil penelitian menunjukkan setelah pemberian minyak deep frying dengan berbagai pengulangan penggorengan didapatkan peningkatan jumlah sel nekrosis pada sel otot jantung tikus putih strain wistar. Pada kelompok kontrol rata-rata jumlah sel nekrosis pada sel otot jantung hanya 4,840. Namun setelah pemberian minyak deep frying dengan 4x penggorengan didapatkan rata-rata jumlah sel nekrosis pada sel otot jantung 12,200. Pada 8x penggorengan didapatkan rata-rata jumlah sel nekrosis pada sel otot jantung 19,080. Pada 16x penggorengan didapatkan peningkatan jumlah sel nekrosis pada sel otot jantung 24,560. Hal ini sesuai dengan penelitian Oeij A, Wahyuni L, Sadiah A (2007) yang menyebutkan bahwa minyak goreng kelapa sawit yang digunakan lebih dari $4 \mathrm{x}$ dan suhu penggorengan 
mencapai $200^{\circ} \mathrm{C}$ akan memudahkan terbentuknya senyawa yang bersifat toksik bagi sel jantung sebagai hasil degradasi peroksidasi lipid dari minyak goreng dengan derajat ketidakjenuhan tinggi yang teroksidasi. Minyak deep frying yang digunakan untuk menggoreng singkong yang mengandung karbohidrat tinggi dapat menambah kerusakan minyak goreng deep frying karena terbentuknya akrilamida yang bersifat toksik, senyawa ini dihasilkan oleh makanan yang mengandung karbohidrat tinggi dan digoreng pada suhu lebih dari 200 (Harahap Y, 2005). Pada penelitian ini menunjukkan bahwa adanya perbedaan yang bermakna antara kelompok kontrol negatif dengan semua kelompok. yaitu terbukti dengan pengaruh pemberian minyak deep frying pada kelompok perlakuan I, II dan III selama 28 hari dan dosis yang diberikan $0,25 \mathrm{ml} / 100$ grBB menunjukkan peningkatkan jumlah sel nekrosis pada sel otot jantung tikus putih strain wistar yang signifikan. Hal ini sesuai dengan penelitian Aisyah S, Balqis U, Friyan E (2013), Anindya (2010), Maulida F (2010).

Jantung merupakan salah satu tempat metabolism lemak. Lemak akan dibawa menuju jaringan adipose dan otot yang mempunyai enzim lipoprotein lipase yang menghidrolisis lemak menjadi asam lemak bebas yang mana asam lemak bebas merupakan sumber energi utama miokardium (Cotran, 2007; Nurdiana, 2011). Tikus yang mendapatkan asupan minyak atau lemak secara berlebihan akan mengakibatkan gangguan terhadap metabolism lemak. Kelebihan asam lemak bebas dalam tubuh akan mengakibatkan peroksidasi lipid yang menghasilkan radikal bebas yang dapat menyebabkan nekrosis sel (Anindiya, 2010; Noviani, 2010). Peningkatan jumlah sel nekrosis pada sel otot jantung disebabkan pemberian minyak deep frying yang mengandung kadar peroksida atau radikal bebas yang tidak dapat dikompensasi terutama di jantung yang memiliki antioksidan yang lebih sedikit dibandingkan organ lain (Siahaan; 2007, Young; 2001). Hal ini sesuai dengan pendapat Ketaren (2008), yaitu semakin sering minyak digunakan tingkat kerusakan minyak akan semakin tinggi dan dapat menyebabkan semakin tingginya nilai peroksida, sehingga jumlah sel yang rusak akan semakin tinggi pula. Minyak deep frying yang digunakan dengan pemanasan suhu tinggi $\left(200^{\circ} \mathrm{C}\right)$ akan mudah teroksidasi sehingga meningkatkan pembentukan spesies oksigen reaktif sehingga akan menyebabkan stres oksidatif pada sel dalam jangka waktu yang kronis sehingga mengakibatkan nekrosis pada sel jantung yang ditandai inti sel piknotik (lebih padat), karioreksis (hancur berkeping-keping), kariolisis (sel menjadi eosinofilik) (Cotran, 2007). Keterbatasan penelitian ini adalah peneliti tidak mengamati mulai dari frekuensi penggorengan yang masih aman digunakan sampai frekuensi penggorengan yang dapat merusak jantung tikus, sehingga frekuensi pnggorengan yang benar-benar aman dapat diketahui lebih pasti.

Minyak deep frying yang digunakan berulang kali dengan suhu tinggi $\left(200-250^{\circ} \mathrm{C}\right)$ dapat menyebabkan lemak tidak jenuh banyak terikat oleh oksigen. Ikatan lemak tidak jenuh dengan oksigen akan menimbulkan proses oksidasi termal. Proses oksidasi akan meningkatkan pembentukan spesies oksigen reaktif yang toksik bagi sel jantung. Spesies radikal bebas ini menyebabkan peroksidasi lipid (kerusakan biomolekul lipid akibat reaktifitas SOR), kerusakan DNA, dan oksidasi protein yang dapat menyebabkan nekrosis sel. Pembentukan senyawa kimia yang bersifat toksik dapat menyebabkan stres oksidatif yaitu ketidakseimbangan antara prooksidan dan antioksidan. Jaringan jantung rentan terhadap radikal bebas yang memicu stres oksidatif hal ini disebabkan karena rendahnya enzim katalase yang berfungsi sebagai scavenger atau antioksidan di jantung. Akumulasi SOR dalam sel akan memicu mediator-mediator inflamasi seperti TNFa, IL-1, IL-6 yang dapat menimbulkan defek permeabilitas membran sel jantung. Hal ini mengakibatkan penurunan fosfolirasi oksidatif sehingga terjadi penurunan sintesis ATP yang menyebabkan penurunan pompa $\mathrm{Na}+$ $\mathrm{K}+$ ATPase. Hal tersebut dapat menyebabkan peningkatan kalsium intrasel yang dapat mengaktivasi enzim katabolisme sel sehingga menyebabkan nekrosis sel.

\section{SIMPULAN}

Berdasarkan hasil dan pembahasan dalam penelitian ini dapat ditarik kesimpulan bahwa terdapat pengaruh yang signifikan antara pemberian minyak deep frying terhadap perubahan histopatologi jantung tikus putih strain wistar, erdapat pemberian minyak deep frying yang bermakna terhadap peningkatan jumlah sel nekrosis pada sel otot jantung tikus putih strain wistar, frekuensi penggorengan yang dapat menyebabkan peningkatan jumlah sel nekrosis pada sel otot jantung tikus putih strain wistar yaitu mulai dari $4 \mathrm{x}$ penggorengan dan semakin tinggi frekuensi penggorengan akan diikuti oleh peningkatan jumlah sel nekrosis pada sel otot jantung.

\section{DAFTAR PUSTAKA}

\section{(Jurnal)}

Aisyah S, Ummu Balqis, Eko Karunia Friyan, 2014, Histopatologi Jantung Tikus Putih (Rattus novergicus) Akibat Pemberian Minyak Jelantah, Jurnal Medika Veterinaria, 8, pp. 1-7.

Anggraeni N, 2009, Pengaruh Lama Paparan Asap Knalpot dengan Kadar CO 1800 PPM terhadap Gambaran Histopatologi Jantung pada Tikus Wistar, JSC, 6, pp. 3-11.

Anindya A, Susianti, Windarti I et al, 2013, Pengaruh Pemberian Minyak Goreng Bekas yang Dimurnikan dengan Buah Mengkudu (Morinda citrifolia) Terhadap Gambaran Histopatologi Sel Otot Jantung Tikus Wistar Jantan, 3, pp. 29-38. Ayu D, Hamzah F, 2010, Evaluasi Sifat Fisiko-Kimia Minyak Goreng yang digunakan oleh pedagang maknanjajanan di Kecamatan Tampan Kotabaru, SAGU, 9, pp. 4-14.

Ayustaningwarno F, 2012, Proses Pengolahan Dan Aplikasi Minyak Sawit Merah pada Industri Pangan, Vitasphere, 2, pp. 1-11.

Barry Sean Pio, 2009, Investigating the Role of the JAK/ STAT and MAPK Pathway in Ischaemia/Reperfusion Injury and Inflammation, Phd thesis, University College London, London.

Cotran Ramzi S, 2007, Jejas, Adaptasi, dan Kematian Sel. In : Asroruddin M, Hartono H, Darmaniah N, Buku Ajar Patologi, 7th edn, EGC, Jakarta, pp 3-30. 
Daud Razali, 2007, Efek Suplementasi Vitamin E Terhadap Perubahan Histopatologis Jantung Mencit yang Diberi Ransum Lemak Tinggi, .Ked.Hewan, 1, pp. 3-5.

Dahlan M, 2008, Statistik untuk Kedokteran dan Kesehatan, 3th edn, Salemba Medika, Jakarta.

Dian M, 2014, Histopatologi Jantung Burung Merpati Akibat Pemberian Ransum Mengandung Minyak Sawit Oksidasi Termal, Jurnal S. Pertanian, 4, pp. 26-32.

Ghidurus M, 2010, Turtoi M, Boskou G, et al, Nutritional and Health Aspects Related to Frying, Romanian Biotechnological Letters, 15, pp. 5675-5681.

Leong X, A.Aishah, U. Nor Aini, Srijit D, et al, 2008, Heated Palm Oil Cuses Rise in Blood and Cardiac Changes in Heart Muscle in Experimental Rats, Archives of Medical Research, 39, pp. 567-572.

Maulida F, 2010, Efek Ekstrak Daun Krokot (Portulaca oleracea L) Terhadap Kadar Alanin Transaminase (ALT) Tikus Putih (Rattus novergicus) yang Diberi Minyak Goreng Deep Frying. Surakarta.

Muazzez G, Zeybek U, Erdamar S, et al, 2007, The Hepatotoxic Effect of Deep-Fried

Sunflower Oil on Rat Livers, Adv Mol Med, 3, pp.35-40. Noviani C, 2010, Pemberian l-carnitine Dapat Memperbaiki Profil Lipid Darah Tikus Putih yang Hiperkolestrolemia, pp. 9-27. Nurdiana H, 2011, Metabolisme Asam Lemak Otot Jantung, Saintika Medika, 7, pp. 48-56.

Oeij, Anindita A, Wahyuni L,et al, 2007, Gambaran Anatomi Mikroskopi dan Kadar Malondialdehida pada Hati setelah pemberian Minyak Kelapa Sawit Bekas Menggoreng, JKM, 7, pp. 15-25.

Putz R, Pabst R, 2006, Organ Visera Dada,In : Sugiharto L, Atlas Anatomi Manusia Sobotta, 22th edn, EGC, Jakarta.

Rukmini A, 2007, Regenerasi minyak goreng bekas dengan arang sekam menekan kerusakan organ tubuh, In: Seminar Nasional Teknologi, pp. 1-9.

Sartika R, 2009, Pengaruh Suhu dan Lama Proses Menggoreng Terhadap Pembentukan Asam Lemak Trans, Makara, 13, pp. 23-28.

Satroasmoro S, Ismael S, 2011, Dasar-dasar Metodologi Penelitian Klinis, 4th edn, Sagung Seto, Jakarta.

Shastry C.S, Patel N.A, Joshi H, et al, 2011, Evaluation Of Effect Of Reused Edible Oils On Vital Organs Of Wistar Rats, NUJHS, 1, pp. 1-6.

Siahaan I, Tina Christina, Nelly Rosdiana et al, 2007, Dampak Kardiotoksik Obat Kemoterapi Golongan Antrasiklin, Sari Pediatri, 9, pp. 151-156.

Siswonoto S, 2008, Hubungan Kadar Malondialdehid Plasma dengan Keluaran Klinis Stroke Iskemik Akut, ilmu penyakit saraf, Universitas Diponegoro, Semarang.

Snell R, 2006, Thorax : Bagian II Cavitas Thoracis, In : Hartanto H, Listiawati E, Suyono Y, et al, 6th edn, EGC, Jakarta, pp. 99-119.

Supranto J, 2007, Teknik Sampling Survey dan Eksperimen, PT Rineka Cipta, Jakarta.

Tsutsui H, Dhintaro K, Shouji M, 2009, Mitochondrial Oxidative Stress and

Dysfunction in Myocardial Remodelling, Cardiovascular Research, 81, pp.449-456.
Xian T, Noor A, Low W, Anisa H, et al, 2012, Reheated Palm Oil Consumption and Risk of Atherosclerosis: Evidence at Ultrastructural Level, Evidence-Based Complementary and Alternative Medicine.

Young I.S, J V Woodside, 2001, Antioxidants in Health and Disease, J Clin Pathol,

(Buku)

Aaronson P, Ward J, 2007, At a Glance Sistem Kardiovaskular, 3th edn, Erlangga, Jakarta.

Gunawan, 2003, Penentuan Angka Peroksida dan Asam Lemak Bebas pada Minyak Kedelai dengan Variasi Menggoreng, JSKA, 6, pp. 17-25.

Guyton A, Hall J, 2007, Otot Jantung ; Jantung Sebagai Pompa dan Fungsi Katup-Katup Jantung, In : Rachman L, Hartanto H, Novrianti A, et al, 11th edn, EGC, Jakarta, pp. 107-119.

Jong W, 2010, Cedera Sel dan Inflamasi, In: Ahmad T, Buku Ajar Ilmu Bedah, 3th edn, EGC, Jakarta, pp. 2-16.

Ketaren S, 2008, Minyak dan Lemak Pangan, 1th edn, Penerbit Universitas Indonesia, Jakarta.

Harahap, Y, 2006, Pembentukkan Akrilamida dalam Makanan dan Analisisnya, 3th edn. Jakarta, pp. 107-116. 